\title{
The Contribution of Economic Sectors to Economic Growth: The Cases of China and India
}

\author{
Fauzi Hussin ${ }^{1, *} \&$ Soo Yoke Yik ${ }^{1}$ \\ ${ }^{1}$ School of Economics, Finance and Banking, Universiti Utara Malaysia, Malaysia \\ *Corresponding author: School of Economics, Finance and Banking, Universiti Utara \\ Malaysia, Malaysia \\ E-mail: fauzi@uum.edu.my
}

Received: July 17, 2012 Accepted: October 14, 2012 Published: December 16, 2012

doi:10.5296/rae.v4i4.2879 URL: http://dx.doi.org/10.5296/rae.v4i4.2879

\begin{abstract}
China and India have recently achieved spectacular economic growth where GDP per capita grows rapidly in both countries. Thus, this study examines the contribution of economic sectors to economic growth in both countries by using time series data from 1978 to 2007 . Three economic sectors were analyzed: agricultural sector, manufacturing sector and services sector. Augmented Dickey-Fuller (ADF) unit-root test shows that the time series data are stationary at first difference. Then, correlation analysis indicates that each economic sector has strong, positive and significant linear relationship with economic growth in China and India. In addition, the results of multiple regression analysis show that agriculture, manufacturing and services sectors have positive relationship with GDP per capita in China and India. However, the contribution of economic sectors to economic growth differs in China and India. Manufacturing sector contributes the highest to China's economic growth while services sector is the highest contributor to India's economic growth.
\end{abstract}

Keywords: China; India; economic growth; economic sectors

JEL Code: O13; O14; R11 


\section{Introduction}

The spectacular economic growth of China since the early 1980s and India since the late 1990s has been a hot topic of discussion in the fields of economic development and economic reform for the past few years. Both countries embarked on economic reforms characterized by deregulation and liberalization, which opened up their economies to international trade and attracted foreign investment. China had undergone reforms earlier and much more aggressively than India, beginning in 1981. On the other hand, India launched widespread economic policy reforms in 1991, in response to fiscal and balance of payments crises. Before their economic reforms, China and India had similar economic structures which are characterized by a large public sector and heavy dependence on agriculture. Before 1980, economic growth in both China and India, as measured by the growth rate of per capita Gross Domestic Product (GDP) was relatively slow.

During their periods of rapid economic growth, China and India had both similar and distinctively different features. Since the early 1980s, China had successfully transformed its manufacturing sector from being state-controlled to being market-oriented. This was due to the rapid development of technology in China. For India, starting in the late 1990s, its reforms had been profound and rewarding in the tradable services sector. However, the growth of technology in India was slightly slower than China as India was focusing more on its labor market instead of the capital market.

\section{Overview of China's Economy}

China's economic reforms have led to profound changes in its economic system. Economic reforms in China began in 1978 when the Chinese concentrated more on the manufacturing sector compared to the agricultural sector. The reason might be because outputs of the agricultural sector are easily affected by the weather. For instance, a long draught season causes serious damage to crops at harvesting season. That might be one of the reasons why China shifted its focus from agriculture to manufacturing.

The development of the manufacturing sector in China presents a sharp contrast to that of the agriculture sector, in terms of both the statistics and the pattern of performance. Manufacturing sector recorded the highest contribution to China's economy during the period of 1978 to 2007. This fact proves that the economic transformation of China has been successful. Moreover, services sector recorded the second largest contribution to the economy from 1978 onwards. Meanwhile, agriculture contributes the least to China's economy compared to the other two sectors after its economic transformation.

The role of the manufacturing sector in the Chinese economy is clearly more significant than that of the agriculture and services sectors, whereby the sector contributes the highest to growth in China. Furthermore, the manufacturing sector generates more employment opportunities to the highly-populated China and it also attracts foreign investor to invest in China. Moreover, as the number of factories increases in China, they also boost the export sector of the nation, bringing in more cash inflow to this huge market. As a result, the 
manufacturing sector acts as a major contributor to economic growth in China since the 1980s.

The contribution of economic sectors to economic growth (real per capita GDP) in China can be evaluated from a different perspective. The manufacturing and services sectors grew consistently with the increase in real per capita GDP in China from 1978 to 2007. However, the ratio of agriculture sector to real per capita GDP fluctuated during the period. Then, agriculture showed a continuous decline when real per capita GDP increased in China from 1990 to 2007 . The manufacturing and services sectors showed increasing trends while the agriculture sector showed a decreasing trend. Moreover, the manufacturing sector is the most developed sector compared to the other sectors. Again, these figures prove that the economic transformation of China has been successful. Hence, manufacturing is the most profitable sector in China as it contributes the most to real GDP per capita during the thirty year period.

\section{Overview of India's Economy}

Though economic liberalization in India can be traced back to the late 1970s, economic reforms began in earnest only in 1991. A balance of payments crisis at the time opened the way for an International Monetary Fund (IMF) program that led to the adoption of a major reform package. After the reformation, India concentrated more on its services sector rather than the agricultural sector. Services sector recorded the highest contribution to India's economy during the period of 1978 to 2007. Services sector grew drastically after 1991, the year when economic reformation began. Meanwhile, agriculture was the second highest contributor during the period of 1978 to 2007 . However, after the economic transformation, manufacturing contributes the least to the Indian economy compared to the other two sectors.

Services sector contributes the highest to economic growth in India. As it is a commonwealth country where the people's command of English is better than China, this factor has led the services sector to growing healthily in outsourced services such as tuition centers, accounting and legal firms, and so on. Besides, as the Information Technology (IT) field in India is developing at a fast pace, its IT specialists are outsourced to many international firms and some are even being outsourced to other countries as far as Malaysia, Singapore and Australia. Therefore, services sector acts as a major contributor to economic growth in India since the 1980s.

The contribution of economic sectors to economic growth (real per capita GDP) in India can be evaluated in a different angle. The manufacturing and services sectors grew consistently with the rise in real per capita GDP in China from 1978 to 2007. However, the ratio of agriculture sector to real GDP per capita fluctuated during the period. Both manufacturing and services sectors showed increasing trends while the agriculture sector showed a slight decline. Moreover, the services sector is the most developed sector compared to the other sectors. However, manufacturing is the most profitable sector in India as it contributes the most to real GDP per capita during the thirty year period. 
The objective of this study is to evaluate the contribution of economic sectors to economic growth in China and India from 1978 to 2007. There are three economic sectors that will be analyzed, namely agriculture (primary sector), manufacturing (secondary sector) and services (tertiary). This study aims to investigate which sector has a more important role in enhancing economic growth in China and India.

\section{Literature Review}

Song, Chu, and Cao (2000) in their empirical study shows that per capita GDP is significantly determined by the stock of capital, foreign direct investment, the amount of infrastructure and human capital. They point out that a higher capital per worker can increase productivity and subsequently increase the per capita GDP. Foreign direct investment could provide the capital required by each province in China. Capital allows local economies to increase the number of projects, thus creating multiplier effects for the areas. Foreign direct investment also introduce new technology and provide spillover effects, and thus could increase productivity in China's economy. Moreover, FDI brings with it western style management which in many aspects enables production and services to become more efficient.

The study by $\mathrm{Fu}$ (2004) has found that exports and foreign direct investment play important roles in creating imbalances between regions in China. Export provides positive and significant impact on the growth of coastal provinces. Furthermore, foreign direct investment which are more concentrated in coastal regions compared to inland regions further increased the income gap and urbanization between regions in China. Rapid growth of exports and foreign direct investment in the coastal regions attracted many laborers from the rural regions. However, government policies that encourage foreign and domestic investment to the rural regions could reduce imbalances between regions in China.

Meanwhile, Lin and Song (2002) study the relationship between per capita GDP growth and investment, foreign direct investment, employment growth, government budget and infrastructure for large and medium sized cities in China from 1991 to 1998. Cross-sectional analysis shows that foreign investment, infrastructure, and government spendings for science and technology have positive relationship with per capita GDP growth, while other government budget as a whole have a negative impact on growth of GDP per capita. However, the relationship between total investment and GDP per capita growth rate is not significant.

Chow (1993) analyzes how physical capital formation in China's economy and five productive sectors namely agriculture, industry, construction, transportation and trade could contribute to economic growth. He discovers that capital formation plays an important role in economic growth. Based on data from 30 provinces in China, Lin (2000) analyzes economic growth in China after economic reforms that began in 1978. He found that regions which invest more in state enterprises grew more slowly compared to regions that invest more in private enterprises. He also notes that openness policy, which is measured by the share of trade in GDP is positively correlated to per capita GDP growth. 
Another study, by Jones, Li, and Owen (2003) employ data from 200 cities in China to identify the differences in per capita income growth of the cities. Among their findings, there exist a significant positive relationship between foreign direct investment and growth in per capita income but a negative correlation between population growth and per capita income growth. On the other hand, there is no significant relationship between domestic investment and human capital with per capita income growth.

Meanwhile, Zhang and Zou (1998) show how the allocation of fiscal resources between the central government and local governments affects the economic growth of all provinces in China between 1978 and1992. Development expenditures of the federal government and regional economic growth show a positive and significant relationship. In contrast, the provincial governments development expenditures are negatively related to real GDP growth of the regions.

According to Okposin, Abdul Halim, and Boon (2003) a lot of theoretical and empirical studies conducted by previous researchers found that foreign direct investment provide either positive or negative effect on economic growth. In general, there are two opposing views on the impact of foreign direct investment in any countries. A more liberal view argues that foreign direct investment are beneficial to output, standard of living, labor usage, technology transfer, foreign markets, balance of payments, and most important is the experience to local investors. Contrary views emphasize the possibility of foreign direct investment tending to be more capital intensive and brings with it problems of large capital outflows in the form of future dividend payments and other remittances. Besides, foreign direct investment results in crowding out or a possible takeover of local entrepreneurs. At the macro level however, the flow of foreign direct investment in developing countries tend to lead to crowd in other investments and thus is associated with increased total investment (UNCTAD, 1992).

Fan and Dickie (2000) point out that the contribution of FDI to economic growth occurs through several channels. FDI has a direct impact as a source of capital formation. As part of private investment, an increase in FDI contributes to an increase in investment, thereby directly contributing to growth. Their study shows that FDI contributes significantly to the economic development of ASEAN-5 in the period 1987-1997. FDI became a major source of capital formation and played a significant role in increasing economic growth. However, according to Blanchard (1997) capital accumulation itself cannot sustain an increase in output due to decreasing returns to capital. To maintain a higher output per worker requires a larger increase in the level of capital per worker, while an increase in technology could sustain growth.

Previous findings on the role of FDI in China mostly show that FDI positively contribute to economic growth in the country. Pomfret (1997) and many other researchers reported that FDI positively and significantly contribute to economic growth in China, either through direct effects (such as increased productivity and promotion of exports) or positive externalities (such as technology transfer) (Zhang, 2001).

Kalirajan (2004) studies the pattern of economic growth for 15 major states in India and the contribution of these states on India's GDP. His research shows that growth patterns are 
different among these states. Only seven states show a consistent increase in growth. Industry-oriented states are seen to grow more rapidly and absorb more labor. The increase in investment and growth in the secondary sector have significant relationship with the GDP growth rates of these states.

Kim and Seo (2003) study the dynamic relationship between the inflow of FDI, domestic investment and economic growth in Korea in the period 1985 - 1999 using Vector Autoregression (VAR) model. They found that in general, FDI is positively related to domestic investment and economic growth, but the relationship is not significant. They also found that an increase in domestic investment tends to crowd out FDI inflows, while positive economic growth provides positive and continuous impact on future FDI.

$\mathrm{Hu}$ and Khan (1997) examine the role of labor and capital inputs in the growth of China's economic aggregate output in the period 1952 to 1994. They found that capital input is the most important source of economic growth in China, which contributed about 65 percent of output growth compared to labor which only contributed about 15 percent of output growth.

Bengoa and Sanchez-Robles (2003) show that FDI has a positive relationship with economic growth but the host country requires human capital, economic stability and liberalized markets in order to obtain long-term benefits from capital inflows.

Wang, Wu and Gao (2010) perform an econometric model analysis for China for the period 1952-2007. Their study shows that there has always been a positive relation between agricultural growth and economic growth and discuss how agriculture contributes to economy growth. Their study concludes that although the share of agriculture in GDP has declined significantly over time, the contribution of agricultural growth has maintained an upward trend and it has made an important market, foreign exchange, factor (finance and labor), and output contributions to non-agricultural growth and thus it remains as an irreplaceable driving force for economic growth. Therefore, agriculture still has a contributory role in economic growth.

Another study by Andzio and Kamitewoko (2004) analyze the influence of agriculture on the GDP of China and three Sub-Saharan Africa (SSA) countries by using multiple regression models. The results show a very interesting insight as to the extent of the importance of agriculture in China and SSA countries. Agriculture remains as the cornerstone of China and the SSA countries where it has a significant effect on GDP in these countries.

Chang, Chen and Hsu (2006) reexamine the relationship between agricultural productivity and economic growth. Their study found that, under a proper condition, in which the revenue generation effect dominates the comparative advantage effect, higher agricultural productivity enhances industrialization and increases long-run economic growth. Moreover, the effect of agricultural productivity was quantitatively assessed, based on the experiences during early stages of economic development in Japan, Taiwan, and Korea. The results show that higher agricultural productivity will subsequently increase industrial sector's employment and thus will enhance economic growth.

Sultan, P. (2008) considers industry value-added as a possible source of economic 
growth in addition to export and import. The regression results show that growth rate of industry value-added can contribute more than the growth rate of export and import towards the growth rate of GDP in Bangladesh. The study found that there exist co-integration and a long run relationship between GDP and industry value-added using bivariate co-integration test. Moreover, the results of the causality tests clearly show that import and/or export by itself cannot contribute to economic growth unless the industrial sector is taken into account. Therefore, the industrial sector plays an important role in increasing economic growth in Bangladesh.

Diaz-Bautista (2003) applies the techniques of co-integration and Granger causality to examine the causal relationship between industrial growth and overall economic performance in the Mexican economy. The empirical results indicate that the industrial sector and overall economy are co-integrated and have a long run relationship. A well-established body of theoretical and empirical researches supports the conclusion that industries are engines of growth.

Libanio (2006) investigates the relation between manufacturing output growth and economic performance from a Kaldorian perspective by estimating Kaldor's first and second growth laws for a sample of seven Latin American economies during the period 1985-2001. The relation between industrial growth and GDP growth can be explained by the effects of manufacturing on productivity levels in the whole economy. The results of this study confirm manufacturing as the engine of growth, and suggest the existence of significant increasing returns in the manufacturing sector in the largest Latin American economies. In addition, the study also concludes that productivity growth seems to respond positively to output growth in the manufacturing sector during the period of analysis. Overall, the results confirm the existence of increasing returns in the manufacturing sector, and the possibility of cumulative growth cycles in the region, based on the expansion of industrial activities.

Elhiraika (2008) investigates the role of structural dynamics and transformation, especially in the form of increased manufacturing share in aggregate output, in accelerating growth and reducing growth volatility in Africa. The study uses data from 36 African countries to examine the key determinants of manufacturing share in aggregate output and its relationship with real GDP growth and growth volatility. The analysis indicates that an increased manufacturing share in total output has the potential to raise GDP growth and reduce growth volatility. Therefore, the study demonstrates that economic transformation through increased share of manufacturing value-added in aggregate output has the potential to accelerate growth and reduce growth volatility.

To determine the relationship between the services industry and economic growth in China, Wang and Li (2010) use an empirical analysis involving unit-roots, co-integration and Granger causality tests based on time series data from 1990 to 2008. The results indicate Granger causality and long-term stable equilibrium relationship between the services industry and economic growth. In other words, the development of the services industry plays an important role in economic growth in China.

$\mathrm{Wu}$ (2007) examines and compares services sector development in two Asia giant 
economies namely China and India. The study investigates the determinants of demand for services and sheds light on the outlook for services sector growth in the two countries. The study reveals that growth in the services sector has mainly been driven by increasing specialization of production, rising standards of living and accelerated urbanization in both societies. There are also some non-economic factors which are difficult to be quantified in the empirical analysis but have played important roles in services development in the two countries. India's services sector is seen as a dominant contributor to GDP growth but China's services sector seems to lag behind.

In addition, Linden and Mahmood (2007) analyze the long run dynamic relationship between sector shares (agriculture, manufacturing and services) and economic growth for 15 Schengen countries in the period 1970 to 2004. Using panel co-integration techniques, there is evidence that the relationship between services-share growth and the growth rate of real per capita GDP is bi-directional. Hence, their study confirms that feedback impact exists between the services sector and the growth rate of real per capita GDP.

In conclusion, based on the discussion of previous researches, this study finds that agriculture, manufacturing and services sectors have positive relationship with economic growth. In other words, the development of these economic sectors will raise economic growth.

\section{Methodology}

\subsection{Data}

Methods are the research techniques used to collect data. The data used in this study were secondary data obtained from the World Development Indicator (WDI) website. This study uses annual time series data from 1978 to 2007. The methodology used for data collection needs to be consistent with the objectives of the study. As this study examines the contribution of economic sectors (agriculture, manufacturing and services) to economic growth in China and India, secondary data is appropriate for the study.

\subsection{Model Specification}

This study investigates the contribution of economic sectors (agriculture, manufacturing and services) to economic growth in China and India from 1978 to 2007. In other words, the study attempts to examine the relationship between economic sectors and economic growth in China and India. Hence, correlation analysis and multiple regression analysis were used to examine the relationship between the dependent variable and the independent variables.

The following model represents the relationship between per capita real Gross Domestic Product (GDP) and the three economic sectors, namely agriculture, manufacturing and services sectors for China and India. The equation for the multiple regression analysis is:

$$
\ln g d p p=\beta_{0}+\beta_{1} \ln a g r+\beta_{2} \ln m a n u+\beta_{3} \ln \operatorname{ser} v+\mu
$$


Where,

$\ln g d p p=$ Real Gross Domestic Product (GDP) per capita

$\ln a g r \quad=$ Share of agricultural sector to real GDP per capita

$\ln$ manu $=$ Share of manufacturing sector to real GDP per capita

$\ln$ serv $=$ Share of services sector to real GDP per capita

$$
\beta_{0}=\text { Intercept }
$$

$\beta_{1}-\beta_{3}=$ Coefficients

$$
\mu=\text { Error Term }
$$

\section{Real GDP per capita}

Real GDP per capita is real gross domestic product $(2000=100)$ divided by average yearly population. Real GDP per capita for China and India are converted into constant U.S. dollars. Dollar figures for real GDP per capita are converted from domestic currencies (Yuan and Rupee) using single year official exchange rates. Real GDP per capita is the dependent variable in this study. The study aims to investigate the relationship between the contribution of economic sectors and economic growth in China and India.

\section{Agriculture Sector}

Agriculture plays an important role in contributing to socio-economic development in many countries. It is the primary source of employment, livelihood, and food security for the majority of rural people. However, due to rapid development and reformation of a country, the agriculture sector has been gradually neglected. Nevertheless, understanding the role of agriculture and its linkages to economic growth is important. Therefore, this study examines the contribution and the importance of agriculture to economic growth in China and India.

\section{Manufacturing Sector}

The industry sector, which includes manufacturing, construction, public utilities and mining, grew rapidly in China and India with high increase in employment. According to Kaldor (1967), manufacturing is an engine of economic growth as industrial goods have a higher-income elasticity of demand. Indeed, GDP growth in countries that were industrialized earlier was largely driven by manufacturing. Thus, this sector is chosen as one of the variables to be analyzed in terms of its contribution to GDP in China and India.

\section{Services Sector}

The services sector is increasingly seen as a means to promote economic development and reduce poverty. It is fast becoming the largest sector, in terms of its share of GDP and employment, in most developing countries. The services sector is highly diverse, ranging from infrastructure services, financial services, business services and social services. Since this sector contributes significantly to GDP in China and India, therefore it is also included as a variable in this study. 


\subsection{Stationarity Test}

This study examines the contribution of economic sectors to economic growth in China and India. The annual time series data cover a period of 30 years from 1987 to 2007. This study uses time series analysis to determine the relationship between economic sectors and economic growth in China and India.

In the first step of the estimation process, this study examines the stationarity properties of the data series. In stationary time series, shocks will be temporary and over time their effects will be eliminated as the series revert to their long run mean values. On the other hand, non stationary series will contain permanent components (Asteriou, 2006).

According to Nelson and Plooser (1982), most of the time series that appear in the economy will have to be differenced in order to become stationary. In fact, most economic variables show a trend and therefore in most cases are non-stationary. Thus, the key to test for non-stationarity is to test for the existence of a unit root.

This study uses Augmented Dickey Fuller (ADF) test (Dickey and Fuller, 1979, 1981) to perform the unit root tests. The ADF test includes extra lagged terms of the dependent and independent variables, which are real GDP per capita, agriculture sector, manufacturing sector and services sector in order to eliminate autocorrelation. This study uses a regression model that includes an intercept and a time trend:

$$
\Delta Y_{t}=\beta_{0}+\beta_{1} t+\beta_{2} Y_{t-1}+\sum_{i=1}^{k} \alpha_{i} \Delta Y_{t-i}+\mu_{t}
$$

The ADF regression tests for the existence of unit roots of $Y_{t}$, namely all model variables at time $t$. The variable $\Delta Y_{t-i}$ represents the first differences with $k$ lags while $\mu_{t}$ is a variable that adjusts the errors of autocorrelation. The coefficients $\beta_{0}, \beta_{1}$ and $\alpha_{i}$ are the values being estimated.

In statistics and econometrics, an Augmented Dickey-Fuller (ADF) test is a test for unit root in a time series sample. It is an augmented version of the Dickey-Fuller test for a larger and more complicated set of time series models. The Augmented Dickey-Fuller (ADF) statistic, used in the test, is a negative number. The more negative it is, the stronger is the rejection of the hypothesis.

Most of the econometric models namely Vector Error Correction Model (VECM), Vector Autoregression Model (VAR) and multiple regressions require stationary data for every variable. However, not all the time series data are stationary which will enable the hypothesis to be rejected. Thus, in this study, ADF unit root test is used to test for stationarity of the variables, namely real GDP per capita, agriculture sector, manufacturing sector and services sector for both countries (China and India). The Augmented Dickey-Fuller (ADF) and Phillips-Perron (PP) unit root tests use intercept and trend and test for variables' stationarity at levels and first differences. 
Table 1: Augmented Dickey-Fuller and Phillips-Perron unit root test results for China and India

\begin{tabular}{lcccccccc}
\hline & \multicolumn{4}{c}{ China } & \multicolumn{3}{c}{ India } \\
\cline { 2 - 9 } & \multicolumn{3}{c}{ Level } & \multicolumn{2}{c}{$1^{\text {st }}$ Differences } & \multicolumn{2}{c}{ Level } & \multicolumn{2}{c}{$1^{\text {st }}$ Differences } \\
\cline { 2 - 9 } $\ln g d p p$ & ADF & PP & ADF & PP & ADF & PP & ADF & PP \\
$\ln$ agr & 2.01 & 2.49 & $-0.55^{*}$ & $-3.28^{*}$ & 3.51 & 2.49 & $-1.31^{*}$ & $-3.28^{*}$ \\
$\ln$ manu & -1.08 & -2.85 & $-3.23^{* *}$ & $-4.30^{* *}$ & -3.52 & -2.71 & $-5.15^{* *}$ & $-4.84^{* * *}$ \\
$\ln$ serv & 2.60 & -2.71 & $-0.18^{*}$ & $-4.84^{* * *}$ & 1.13 & 1.03 & $-1.93^{*}$ & $-2.45^{* *}$ \\
${ }^{*},{ }^{* *}$ indicate that the tau-values are significant at $5 \%$ and $1 \%$, respectively. & & &
\end{tabular}

Table 1 reports the results of the ADF and PP unit-root test for four variables in China and India in the levels and first differences. Interestingly, all the variables are not stationary in their levels but become stationary after first differencing. Hence, all four variables fail to reject the unit-root hypothesis at levels but able to reject it at first differences. Level of significance of the ADF statistics for all variables is one and five percent (1\% and $5 \%)$. In addition, the results show that the series are integrated at the first differences, $I(1)$. Since all the time series variables are integrated at the same order, the data set is appropriate for further analysis. All the dependent and independent variables are stationary at the first differences.

\section{Empirical Results}

\subsection{Results of Regression Analysis}

One of the measures of goodness of fit of regression models is the coefficient of determination, $\mathrm{R}^{2}$. It is the proportion of the total variation in the dependent variable that is explained or accounted for by the variation in the independent variables. In this study, there are two countries being investigated, China and India. Therefore, the regression model results are explained separately.

Table 2 displays the results of the multiple regression analysis to determine the relationship between real GDP per capita $(\mathrm{Y})$ and agriculture sector $\left(\mathrm{X}_{1}\right)$, manufacturing sector $\left(\mathrm{X}_{2}\right)$ and services sector $\left(\mathrm{X}_{3}\right)$ in China. The equation for this model is:

$\ln g d p p=\beta_{0}+\beta_{1} \ln a g r+\beta_{2} \ln m a n u+\beta_{3} \ln \operatorname{ser} v+\varepsilon$

$\ln g d p p=-21.59+0.1725 \ln a g r+0.6695 \ln$ manu $+0.2361 \ln s e r v+\varepsilon$

$$
\begin{array}{lll}
(-17.19) \quad(2.212) \quad(27.218)
\end{array}
$$

The coefficients of $X_{1}, X_{2}$ and $X_{3}$ are statistically significant at the $95 \%$ confidence level where their absolute t-values are more than 2 and the p-values are less than 0.05 . Thus, hypothesis null $\left(\mathrm{H}_{0}\right)$ is rejected. This implies that these three economic sectors are related to 
real GDP per capita in China. In addition, these three economic sectors have positive relationship with real GDP per capita due to the positive values of the coefficients of $\mathrm{X}_{1}, \mathrm{X}_{2}$ and $\mathrm{X}_{3}$.

The coefficient of determination $\left(\mathrm{R}^{2}\right)$ shows that a $98.23 \%$ variation in real GDP per capita can be explained by these three independent variables. The subsectors of agriculture are forestry, hunting, and fishing, as well as cultivation of crops and livestock production. In addition, the subsectors of services are wholesale and retail trade (including hotels and restaurants), transport, government, financial, professional and personal services such as education, health care, and real estate services. There are many subsectors in agriculture and services, some of them bring high value-added to real GDP per capita in China. Therefore, the coefficient of determination $\left(\mathrm{R}^{2}\right)$ recorded such a high value $(98.23 \%)$. The remaining $1.77 \%$ of the variation is associated with other factors not captured in this model.

The interpretation of the coefficient of $\mathrm{X}_{1}$ is, if valued-added for the agriculture sector increases by $1 \%$, real GDP per capita is expected to increase by $0.1725 \%$. Moreover, if value-added for the manufacturing sector $\left(\mathrm{X}_{2}\right)$ increases by $1 \%$, real GDP per capita is expected to increase by $0.6695 \%$. In addition, if value-added for the services sector $\left(\mathrm{X}_{3}\right)$ increases by $1 \%$, real GDP per capita is expected to rise by $0.2362 \%$.

In conclusion, agriculture, manufacturing and services sectors have some impact on real GDP per capita in China. According to the results, manufacturing is the highest contributor to real GDP per capita in China. This is because China has successfully transformed its manufacturing sector from being state-controlled to being market-oriented since the early 1980s. This success is attributed to a number of factors, including price deregulation, ownership reform of state owned enterprises (SOEs), private sector development, FDI inflow, and trade liberalization ( $\mathrm{Li}$ and Zhang, 2008). In other words, these factors enhance the contribution of the manufacturing sector to economic growth in China after the economic transformation.

Table 2: Results of Multiple Regression Analysis for China

\begin{tabular}{lcccc}
\hline \multicolumn{1}{c}{ Variables } & Coefficient & Std. Error & t-Statistic & P Value \\
\hline Constant & -21.59009 & 1.255397 & -17.19782 & 0.0000 \\
$\ln$ agr & 0.172482 & 0.077964 & 2.212339 & 0.0367 \\
$\ln$ manu & 0.669476 & 0.092750 & 7.218093 & 0.0000 \\
$\ln$ serv & 0.236154 & 0.055901 & 4.224481 & 0.0003 \\
\hline
\end{tabular}

F-Statistic $=444.318 \quad \mathrm{R}^{2}=0.982 \quad \mathrm{D}-\mathrm{W}=1.830$

Table 3 shows the results of multiple regression analysis between real GDP per capita and agriculture, manufacturing and services sectors in India. The equation for this model is:

$$
\begin{aligned}
\ln g d p p= & \beta_{0}+\beta_{1} \ln a g r+\beta_{2} \ln \text { manu }+\beta_{3} \ln \operatorname{ser} v+\varepsilon \\
\ln g d p p= & -13.89+0.142 \ln a g r+0.117 \ln \text { manu }+0.4789 \ln s e r v+\varepsilon \\
(-4.842) & (2.767)
\end{aligned}
$$


The coefficients of $X_{1}, X_{2}$ and $X_{3}$ are statistically significant at the $95 \%$ confidence level since their absolute t-values are more than 2 and the p-values are less than 0.05 . Thus, the null hypothesis $\left(\mathrm{H}_{0}\right)$ is rejected. This implies that the three economic sectors have a relationship with real GDP per capita in India. In addition, the three economic sectors have positive relationship with real GDP per capita due to the positive values of the coefficients of $\mathrm{X}_{1}, \mathrm{X}_{2}$ and $\mathrm{X}_{3}$.

The coefficient of determination $\left(\mathrm{R}^{2}\right)$ shows that $77.46 \%$ variation in real GDP per capita can be explained by the three independent variables. The subsectors of agriculture are forestry, hunting, and fishing, as well as cultivation of crops and livestock production. In addition, the subsectors of services are wholesale and retail trade (including hotels and restaurants), transport, government, financial, professional and personal services such as education, health care, and real estate services. There are many subsectors in agriculture and services, some of them bring high value- added to real GDP per capita in India. Therefore, the coefficient of determination $\left(\mathrm{R}^{2}\right)$ registers such a high value $(77.64 \%)$. The remaining $22.36 \%$ of the variation in the dependent variable is explained by other factors not included in this model.

The interpretation of the coefficients of $\mathrm{X}_{1}$ is, if value-added for the agriculture sector increases by $1 \%$, real GDP per capita is expected to increase by $0.1420 \%$. In contrast, if value-added for the manufacturing sector $\left(\mathrm{X}_{2}\right)$ increases by $1 \%$, real GDP per capita is expected to increase by $0.1170 \%$. Lastly, if value-added for the services sector $\left(\mathrm{X}_{3}\right)$ increases by $1 \%$, real GDP per capita is expected to increase by $0.4789 \%$.

In conclusion, agriculture, manufacturing and services sectors have an impact on real GDP per capita in India. According to the results, services sector contributes the highest to real GDP per capita in India. This is because after India began its economic reform in 1991, there have been some main consequences of its economic reform such as growth of private enterprises, large inflow of FDI and increased volume of foreign trade (Bloom, Canning, $\mathrm{Hu}$, Liu, Mahal and Yip, 2006). Therefore, it can be seen that India's reform has been most rewarding in its services sector and this sector has contributed significantly to economic growth.

Table 3: Results of Multiple Regression Analysis for India

\begin{tabular}{lcccc}
\hline \multicolumn{1}{c}{ Variables } & Coefficient & Std. Error & t-Statistic & P Value \\
\hline Constant & -13.88811 & 2.868047 & -4.842358 & 0.0003 \\
$\ln$ agr & 0.141987 & 0.095851 & 2.481326 & 0.0167 \\
$\ln$ manu & 0.116963 & 0.066191 & 2.767065 & 0.0099 \\
$\ln$ serv & 0.478872 & 0.127897 & 3.744212 & 0.0022 \\
\hline
\end{tabular}

F-Statistic $=13.603 \quad \mathrm{R}^{2}=0.775 \quad$ Durbin Watson $=1.856$




\section{Concluding Remarks}

This study has focused on examining the contribution of economic sectors to economic growth in China and India from 1978 to 2007. There are three economic sectors which have been selected for this study, namely agriculture, manufacturing and services sectors. The reason for selecting these three economic sectors as the independent variables in the study is due to their development trend (agriculture, manufacturing and services) from 1978 to 2007. The results of the study indicate that manufacturing sector is the highest contributor to real GDP per capita in China. If value-added for the manufacturing sector $\left(\mathrm{X}_{2}\right)$ increases by $1 \%$, real GDP per capita in China is expected to increase by $0.6695 \%$. On the other hand, services sector is the biggest contributor to real GDP per capita in India. If value-added for the services sector $\left(\mathrm{X}_{3}\right)$ increases by $1 \%$, real GDP per capita in India is expected to rise by $0.4789 \%$. Therefore, the importance of the contribution of each economic sector to economic growth differs in China and India. This is due to the differences in background, level of productivity, technology, professional labor, resources, labor forces and policies in the two countries.

Finally, the services sector is a more significant contributor to economic growth in both countries. Therefore this sector should be given priority in the planning of national development policies. In addition, the countries should devise strategies to attract more foreign investments into their manufacturing and agriculture sectors.

\section{References}

Bengoa, G. S., \& Sanchez-Robles, B. (2003). Foreign direct investment, economic freedom and growth: New evidence from Latin America. European Journal of Political Economy, 19(3), 529-545. http://dx.doi.org/10.1016/S0176-2680(03)00011-9

Blanchard, O. (1997). Macroeconomics. New Jersey: Prentice Hall, Inc.

Chang, J. J., Chen, B.L., \& Hsu, M. (2006). Agricultural productivity and economic growth: Role of tax revenues and infrastructures. Southern Economic Journal, 72, 891-914. http://dx.doi.org/10.2307/20111859

Chow, G. C. (1993). Capital formation and economic growth in China. Quarterly Journal of Economics, 108, 809-842. http://dx.doi.org/10.2307/2118409

Diaz-Bautista, Alejandro. (2003). Mexico's industrial engine of growth: Cointegration and causality. Revista Momento Economico, 126, 34 - 41.

Dicker, D. A., \& Fuller, W. A. (1979). Distribution of the estimation for autoregressive time series with a unit root. Journal of American Statistical Association, 74, 427-431.Dicker, D. A., \& Fuller, W. A. (1981). Likeihood ration statistics for autoregreesive time series with a unit root. Econometrica, 49, 1057-1072.

Elhiraika, A. B. (2008). Promoting manufacturing to accelerate economic growth reduce volatility in Africa. Paper prepared at the African Economic Conference, jointly organized by the African Development Bank and UNECA in Tunis, Tunisia. 
Fan, X., \& Dickie, P. M. (2000). The contribution of foreign direct investment to growth and stability: A post-crisis ASEAN-5 review. ASEAN Economic Bulletin, 13(3), 312-323. http://dx.doi.org/10.1355/AE17-3F

$\mathrm{Fu}, \mathrm{X}$. (2004). Limited linkages from growth engines and regional disparities in China. Journal of Comparative Economics, 32, 148-164. http://dx.doi.org/10.1016/j.jce.2003.10.004

Hu, Z. F., \& Khan, M. S. (1997). Why is China growing so fast ? International Monetary Fund, 44(1), 103-131.

Jones, D. C., Li, C., \& Owen, L. (2003). Growth and regional inequality in China during the reform era. China Economic Review, 14, 186-200. http://dx.doi.org/10.1016/S1043-951X(03)00022-1

Kaldor, N. (1967). Strategic factor in economic development. New York: New York State School of Industrial and Labor Relations.

Kalirajan, K. (2004). Economic reform and the transmission of growth impulses across Indian states. International Journal of Social Economics, 31(5/6), 623-636. http://dx.doi.org/10.1108/03068290410529434

Kim, D. D.-K., \& Seo, J.-S. (2003). Does FDI inflow crowd out domestic investment in Korea? Journal of Economic Studies, 30(6), 605-622. http://dx.doi.org/10.1108/01443580310504462

Li, Y. F., \& Zhang, B. (2008). Development path of China and India and the challenges for their sustainable growth. World Economy, 31, 1277-1291. http://dx.doi.org/10.1111/j.1467-9701.2008.01128.x

Libanio, G. (2006). Manufacturing industry and economic growth in Latin America: A Kaldorian approach. CEDEPLAR, Brazil: Federal University of Minas Gerais.

Lin, S. (2000). Resource allocation and economic growth in China. Economic Inquiry, 38, 515-526.

Lin, S., \& Song, S. (2002). Urban economic growth in China: Theory and evidence. Urban Studies, 39(12), 2251-2266. http://dx.doi.org/10.1080/0042098022000033854

Linden, M., \& Tahir Mahmood. (2007). Long run relationships between sector shares and economic growth - A Panel Data Analysis of the Schengen Region. Keskustelualoitteita, $50,1-36$.

Nelson, C., \& Plosser, C. I. (1982). Trend and random walks in macroeconomic time series: Some evidence and implication. Journal of Monetary Economics, 10, 139-162. http://dx.doi.org/10.1016/0304-3932(82)90012-5

Pomfret, R. (1997). Growth and transition: Why has China's performance been so different. Journal of Comparative Economics, 25, 422-440. http://dx.doi.org/10.1006/jcec.1997.1477 


\section{Macrothink}

Sekaran, U. (2000). Research Methods for Business: A skill-building approach. New York: John Wiley \& Sons.

Song, S., Chu, G. S., \& Cao, R. (2000). Intercity regional disparity in China. China Economic Review, 11, 246-261. http://dx.doi.org/10.1016/S1043-951X(00)00020-1

Sultan, P. (2008). Trade, industry and economic growth in Bangladesh. Journal of Economic Cooperation, 29, 71-92.

United Nations Conference on Trade and Development (UNCTD). (1992). World Investment Report 1992. New York and Geneva: United Nations.

Wang, S., \& Li, D. (2010). A empirical analysis on the relationship between service industry and economic growth. Proceedings of 2010 International Conference on Industry Engineering and Management . ISBN: 978-0-9806854-3-5.

Wang, X. Z., Wu, S. L., \& Gao, F. (2010). The relationship between economic growth and agricultural growth: The case of China. Paper presented at International Conference on E-Business and E-Government (ICEE), Guanghou, China, 7-9 May.

Wilfrid, A.H., \& Edwige, K. (2004). Role of agriculture in economic development of developing countries: Case Study of China and Sub-Saharan Africa (SSA). Journal of Agriculture and Social Research, 4, 1 - 18.

World Development Indicator. Retrieved from http://data.worldbank.org/indicator

Zhang, K. H. (2001). How does foreign direct investment affect economic growth in China? Economics of Transition, 9(3), 679-693. http://dx.doi.org/10.1111/1468-0351.00095

Zhang, T., \& Zou, H.-f. (1998). Fiscal decentralization, public spending, and economic growth in China. Journal of Public Economics, 67, 221-240. http://dx.doi.org/10.1016/S0047-2727(97)00057-1

\section{Copyright Disclaimer}

Copyright reserved by the author(s).

This article is an open-access article distributed under the terms and conditions of the Creative Commons Attribution license (http://creativecommons.org/licenses/by/3.0/). 